\title{
ANALISIS PENGARUH CAREER GROWTH, COMPENSATION, DAN JOB SATISFACTION SEBAGAI VARIABEL INTERVENING TERHADAP TURNOVER INTENTION KARYAWAN DI PT. IMORA MOTOR (HONDA JAKARTA CENTER)
}

\author{
Wandhan Galuh Chalyana \\ Program Study Magister Management Universitas Tarumanagara \\ chalyaa.mii@gmail.com \\ Mukti Rahardjo \\ Dosen Program Study Magister Management Universitas Tarumanagara
}

\begin{abstract}
Turnover intention is essentially a desire to move employees from one workplace to another. This is a company's challenge in maintaining labor competition. Human resources are believed to be the main factor determining the success of an organization. This study aims to determine the effect of Career Growth on Turnover Intention Employees, Compensation effect on Turnover Intention, And influence Job Satisfaction as variable intervening to TurnOver Employees in PT. Imora Motor (Honda Jakarta Center). This research is expected to be able to help find out the main factors causing employee turnover intention and overcome the problem of Turnover Intention so that it helps companies reduce losses both in terms of costs and time. This research uses quantitative research methodology simple random sampling. The method used in sampling is purposive sampling. Purposive sampling is a sampling method by formulating certain criteria using primary data sources. The number of samples in this research were 164 respondents. The variables used in this study used Dependent Variables, Intervening Variables and Independent Variables, then to get conclusions in the research that carried out statistical tests with the aim of finding out which dependent variables would influence the independent variables in the study. This study used SPSS version 23 to carry out statistical tests, Results of testing that has been done, partial regression test $(\mathrm{t})$ shows that each is dependent the variables studied (career growth, compensation, and job satisfaction) have a significant influence on independence variable (Turnover Intention).
\end{abstract}

Keyword : Career Growth, Compensation, Job Satisfaction, Turnover Intention.

Abstrak : Turnover intention pada dasarnya adalah keinginan berpindah karyawan dari satu tempat kerja ke tempat kerja lainnya. Hal ini merupakan suatu tantangan perusahaan dalam mempertahankan persaingan tenaga kerja. Sumber daya manusia diyakini menjadi faktor utama penentu kesuksesan sebuah organisasi. Penelitian ini bertujuan untuk mengetahui pengaruh Career Growth terhadap Turnover Intention Karyawan, pengaruh Compensation terhadap Turnover Intention, dan pengaruh Job Satisfaction sebagai variable intervening terhadap Turnover Karyawan di PT. Imora Motor (Honda Jakarta Center). Penelitian ini diharapkan mampu membantu mengetahui faktor utama penyebab turnover intention karyawan dan mengatasi problematika mengenai Turnover Intention sehingga membantu perusahaan dalam mengurangi kerugian baik dari segi biaya maupun waktu. Penelitian ini menggunakan metodologi penelitian kuantitatif simple random sampling. Metode yang dilakukan dalam pengambilan sampel yaitu purposive sampling. Purposive sampling yaitu metode pengambilan sampel dengan merumuskan beberapa kriteria tertentu dengan menggunakan sumber Data Primer. Penelitian ini menggunakan 164 responden. Variabel yang digunakan pada penelitian ini menggunakan Variable Dependen, Variable Intervening dan Variable Independen kemudian untuk mendapatkan kesimpulan dalam penelitian yang 
dilakukan uji statistik dengan tujuan untuk mengetahui variabel dependen mana yang akan mempengaruhi variabel independen dalam penelitian. Penelitian ini menggunakan SPSS versi 23 untuk melakukan uji statistik, Hasil pengujian yang telah dilakukan, uji regresi parsial (t) menunjukkan bahwa masing-masing variabel dependen yang diteliti (pertumbuhan karier, kompensasi, dan kepuasan kerja) memiliki pengaruh yang signifikan terhadap variabel independen (Turnover Intention).

\section{PENDAHULUAN}

Menjaga dan mempertahankan karyawan menjadi sebuah tantangan yang harus dihadapi perusahaan. Sumber daya manusia dapat mempengaruhi efektifitas dan efisiensi organisasi (Simamora, 2006). Kualitas para karyawan adalah aset utama bagi perusahaan untuk memiliki daya saing yang kuat, dan sebagai kekuatan menghadapi ancaman eksternal.

Penelitian ini dilakukan di PT. Imora Motor (Honda Jakarta Center). Penelitian ini diharapkan mampu membantu mengetahui faktor utama penyebab turnover intention karyawan dan mengatasi problematika mengenai Turnover Intention sehingga membantu perusahaan dalam mengurangi kerugian baik dari segi biaya maupun waktu.

PT. Imora Motor memiliki sebuah tantangan dalam hal menghadapi tingginya TurnOver karyawan dan keinginan berpindah karyawan yang belum terealisasikan sehingga PT. Imora Motor sendiri masih memerlukan banyak perbaikan agar manajemen yang berjalan dapat mempertahankan kelangsungan perusahaan. Dengan tingkat turnover yang tinggi dapat menimbulkan berbagai kerugian baik dari segi biaya maupun waktu dalam pelatihan namun sia-sia akibat turnover yang mengakibatkan adanya perekrutan dan pelatihan kembali. Permasalahan yang kerap kali terjadi tidak dapat dihindari, akan tetapi permasalahan ini dapat diturunkan seminimal mungkin. Pada Table diberikan data jumlah Turnover Pada PT. Imora Motor.

Table

Data Turnover PT. Imora Motor, periode tahun 2015-2017

\begin{tabular}{|l|l|l|l|l|l|l|l|}
\hline \multirow{2}{*}{ No. } & \multirow{2}{*}{ Bulan } & \multicolumn{2}{|l|}{2015} & \multicolumn{2}{l|}{2016} & 2017 \\
\cline { 3 - 8 } & & In & Out & In & Out & In & Out \\
\hline 1 & January & 6 & 7 & 9 & 9 & 15 & 10 \\
\hline 2 & February & 4 & 5 & 12 & 4 & 19 & 2 \\
\hline 3 & March & 12 & 5 & 15 & 7 & 18 & 8 \\
\hline 4 & April & 8 & 11 & 35 & 7 & 14 & 7 \\
\hline 5 & May & 10 & 6 & 20 & 3 & 16 & 4 \\
\hline 6 & June & 14 & 13 & 3 & 5 & 3 & 9 \\
\hline 7 & July & 4 & 5 & 15 & 9 & 23 & 12 \\
\hline 8 & August & 4 & 5 & 28 & 5 & 4 & 8 \\
\hline 9 & September & 3 & 5 & 18 & 12 & 10 & 6 \\
\hline 10 & October & 5 & 3 & 10 & 19 & 5 & 7 \\
\hline 11 & November & 8 & 6 & 13 & 4 & 2 & 10 \\
\hline 12 & December & 4 & 8 & 13 & 13 & 1 & 5 \\
\hline Total & & $\mathbf{8 2}$ & $\mathbf{7 9}$ & $\mathbf{1 9 1}$ & $\mathbf{9 7}$ & $\mathbf{1 3 0}$ & $\mathbf{8 8}$ \\
\hline
\end{tabular}

Sumber : Data Perusahaan PT Imora Motor tahun 2015 - tahun 2017

Dari data yang telah diuraikan di atas dapat ditarik kesimpulan bahwa pada tahun 2015 hingga 2017 angka Turnover PT. Imora Motor sangat tinggi hingga diatas 50\% karyawan yang mengundurkan diri tahun 2015 hingga 2017. Hal ini menunjukkan bahwa Turnover merupakan masalah yang perlu mendapatkan perhatian pada perusahaan tersebut sehingga kajian mengenai Turnover Intention yang merupakan perilaku awal sebelum Turnover diperlukan guna mengantisipasi terjadinya Turnover Intention. Berdasarkan uraian 
tersebut diatas maka penulis tertarik untuk mengadakan penelitian mengenai "Analisis Pengaruh Career Growth, Compensation, dan Job Satisfaction sebagai Variabel Intervening Terhadap Turnover Intention Karyawan di PT Imora Motor (Honda Jakarta Center)".

\section{TINJAUAN PUSTAKA}

Secara sederhana, Turnover dalam bahasa indonesia diartikan sebagai tingkat kepindahan. Faktor-faktor yang termasuk dalam keinginan berpindah karyawan adalah kepuasan kerja, masalah kinerja, lingkungan kerja, harapan pekerjaan yang belum terpenuhi, stres kerja, kurangnya peluang pengembangan karir dan sebagainya. Menurut Sommers (1995) dalam Purwanti (2008) turnover merupakan angka yang menggambarkan jumlah atau seberapa banyak karyawan yang keluar dalam suatu organisasi atau meninggalkan organisasi tempat dimana ia bekerja, untuk pindah ketempat lain atau berhenti bekerja. Hal tersebut dipengaruhi oleh Pertumbuhan karir perusahaan yang baik akan menciptakan motivasi yang tinggi terhadap karyawan sehingga akan berdampak baik bagi tujuan perusahaan tersebut. Menurut Simamora (2001:505) karir adalah " Urutan aktifitas-aktifitas yang berkaitan dengan pekerjaan dan perilaku-perilaku, nilai-nilai, dan aspirasi seseorang selama rentang hidup orang tersebut". Kemudian selain faktor pertumbuhan karir, faktor kompensasi juga memiliki keterlibatan terhadap Turnover Intention, Menurut Dessler (2007:72) kompensasi diartikan "Semua bentuk pembayaran atau imbalan yang diberikan kepada karyawan dan berasal dari pekerjaan mereka". Pertumbuhan karir dan kompensasi akan menumbuhkan rasa kepuasan kerja, menurut Serrano dan Vieira sebelumnya dikemukakan oleh Luthans (2002) bahwa implikasi kepuasan kerja sering dikaitkan dengan peningkatan kinerja individual, kinerja organisasi, tingkat perputaran kerja dan kemangkiran.

\section{Hipotesis Penelitian}

Menurut Sugiyono (2000:161) Hipotesis merupakan jawaban sementara terhadap rumusan masalah penelitian. Hipotesis dapat dikatakan sebagai pendugaan sementara mengenai hubungan variabel yang akan diuji sebenarnya.

Berdasarkan masalah penelitian yang telah dirumuskan pada bagian sebelumnya, maka penulis menarik sebuah hipotesis penelitian ini sebagai berikut : "Career Growth, Compensation, dan Job Satisfaction sebagai Variabel Intervening berpengaruh secara signifikan Terhadap Turnover Intention Karyawan di PT Imora Motor (Honda Jakarta Center)".

\section{METODOLOGI PENELITIAN}

Penelitian ini dilakukan di PT Imora Motor (Honda Jakarta Center) yang beralamat di Jalan Pangeran Jayakarta nomor 50 Jakarta Pusat. Waktu penelitian dilaksanakan pada bulan Oktober 2018 hingga selesai. Penelitian ini menggunakan metodologi penelitian kuantitatif simple random sampling. Metode yang dilakukan dalam pengambilan sampel yaitu purposive sampling. Sample dari penelitian ini adalah karyawan PT Imora Motor dengan populasi sample adalah 164 responden PT Imora Motor. Teknik analisis data dilakukan dengan Uji Regresi dan Uji Korelasi.

\section{Populasi dan Sampel}

Populasi dari penelitian ini yaitu seluruh karyawan yang bekerja di PT. Imora Motor yang ada di kota Jakarta Pusat. Metode yang dilakukan dalam pengambilan sampel yaitu purposive sampling. Purposive sampling yaitu metode pengambilan sampel dengan menetapkan beberapa kriteria tertentu. Ketentuan untuk menjadi objek penelitian ini yaitu:

- Merupakan karyawan yang bekerja secara tetap, bukan karyawan magang ataupun karyawan outsourching.

- Minimal masa kerja 1 tahun. 


\section{HASIL DAN PEMBAHASAN}

Deskripsi objek penelitian merekap seluruh tanggapan dari 164 responden atas masing-masing indikator yang memprediksi variabel career growth, compensation, job satisfaction dan turnover intention.

Hasil Hipotesis

Hipotesis 1: Career Growh berpengaruh positif terhadap Job Satisfaction

Berdasarkan hasil pengolahan yang ditampilkan pada tabel 4.15 di atas, dapat diketahui bahwa pertumbuhan karir berpengaruh positif terhadap kepuasan kerja, di mana kompensasi memperoleh nilai koefisien regresinya sebesar 0.495 dan memiliki nilai signifikansi sebesar 0.000. Nilai signifikansi yang lebih kecil dari 0.05 menunjukkan kompensasi berpengaruh positif dan signifikan terhadap kepuasan kerja. Dengan demikian, $\mathrm{H}_{1}$ tidak ditolak.

Hipotesis 2: Career Growth berpengaruh positif terhadap Turnover Intention

Hipotesis pertama penelitian ini menyatakan pertumbuhan karir berpengaruh positif terhadap turnover intention. Berdasarkan hasil pengolahan yang ditampilkan pada tabel 4.16 diperoleh nilai koefisien regresinya sebesar 0.165 dengan signifikansi sebesar 0,011 yang nilai signifikansinya lebih besar dari 0,05. maka dapat disimpulkan bahwa variabel petumbuhan karir memiliki pengaruh positif dan tidak signifikan terhadap turnover intention. Dengan demikian $\mathrm{H}_{2}$ ditolak.

Hipotesis 3: Compensation berpengaruh positif terhadap Job Satisfaction

Berdasarkan hasil pengolahan yang ditampilkan pada tabel 4.15 di atas, dapat diketahui bahwa kompensasi berpengaruh positif terhadap kepuasan kerja, di mana kompensasi memperoleh nilai koefisien regresinya sebesar 0.269 dan memiliki nilai signifikansi sebesar 0.000. Nilai signifikansi yang lebih kecil dari 0.05 menunjukkan kompensasi berpengaruh positif dan signifikan terhadap kepuasan kerja. Dengan demikian, $\mathrm{H}_{3}$ tidak ditolak.

Hipotesis 4: Compensation berpengaruh positif terhadap Turnover Intention

Berdasarkan hasil pengolahan yang ditampilkan pada tabel 4.16 di atas, dapat diketahui bahwa kompensasi berpengaruh positif terhadap turnover intention, di mana kompensasi memperoleh nilai koefisien regresinya sebesar 0.149 dan memiliki nilai signifikansi sebesar 0.006. Nilai signifikansi yang lebih kecil dari 0.05 menunjukkan kompensasi berpengaruh positif dan signifikan terhadap turnover intention. Dengan demikian, $\mathrm{H}_{4}$ tidak ditolak.

Hipotesis 5: Job Satisfaction berpengaruh positif terhadap Turnover Intention

Berdasarkan hasil pengolahan yang ditampilkan pada tabel 4.16 di atas, dapat diketahui bahwa kepuasan kerja berpengaruh positif terhadap turnover intention, di mana kompensasi memperoleh nilai koefisien regresinya sebesar 0.190 dan memiliki nilai signifikansi sebesar 0.002. Nilai signifikansi yang lebih kecil dari 0.05 menunjukkan kepuasan kerja berpengaruh positif dan signifikan terhadap turnover intention. Dengan demikian, $\mathrm{H}_{5}$ tidak ditolak.

Hipotesis 6: Career Growth, Compensation dan Job Satisfaction berpengaruh terhadap Turnover Intention

Berdasarkan tabel 4.14 diketahui bahwa secara bersama-sama variabel independen memiliki pengaruh yang signifikan terhadap Turnover Intention. Hal ini dapat dibuktikan dari sig $\mathrm{F}$ signifikansi pada table uji F dengan struktur modal sebagai variable dependen sebesar 0,000. Nilai signifikansi ini di bawah dari sig $\alpha(0.05)$, sehingga dapat disimpulkan terdapat pengaruh yang signifikan dari variabel independen terhadap variabel dependen secara bersama (simultan), maka semua variabel independen tersebut menunjukkan gejala Uji F. dengan demikian, hipotesis 6 tidak ditolak.

Hipotesis 7: Career Growth dan Compensation berpengaruh terhadap Turnover Intention Berdasarkan tabel 4.13 diketahui bahwa secara bersama-sama variabel independen memiliki pengaruh yang signifikan terhadap Turnover Intention. Hal ini dapat dibuktikan dari sig F signifikansi pada table uji F dengan struktur modal sebagai variable dependen sebesar 0,000. Nilai signifikansi ini di bawah dari sig $\alpha$ (0.05), sehingga dapat disimpulkan terdapat 
pengaruh yang signifikan dari variabel independen terhadap variabel dependen secara bersama (simultan), maka semua variabel independen tersebut menunjukkan gejala Uji $\mathrm{F}$. dengan demikian, hipotesis 7 tidak ditolak.

Hipotesis 8: Career Growth dan Compensation berpengaruh terhadap Turnover Intention melalui Job Satisfaction

Besarnya pengaruh langsung career growth terhadap job satisfaction sebesar 0.495 dan pengaruh langsung job satisfaction terhadap turnover intention sebesar 0.190 sehingga pengaruh career growth terhadap turnover intention melalui job satisfaction sebesar 0.094 lebih kecil dari pengaruh langsung career growth terhadap turnover intention sebesar 0.165 sehingga dapat dinyatakan pengaruh variabel mediasi job satisfaction tidak signifikan. Besarnya pengaruh langsung compensation terhadap job satisfaction sebesar 0.269 dan pengaruh langsung job satisfaction terhadap turnover intention sebesar 0.190 sehingga pengaruh compensation terhadap turnover intention melalui job satisfaction sebesar 0.051 lebih kecil dari pengaruh langsung compensation terhadap turnover intention sebesar 0.149 sehingga dapat dinyatakan pengaruh variabel mediasi job satisfaction tidak signifikan. Dengan demikian, dapat dinyatakan bahwa hipotesis 8 ditolak.

\section{KESIMPULAN DAN SARAN}

\section{Kesimpulan}

Penelitian ini bertujuan untuk mengetahui pengaruh Kompensasi dan Pertumbuhan Karir dengan Kepuasan Kerja sebagai variable intervening terhadap Turnover Intention pada perusahaan PT Imora Motor. Berdasarkan hasil analisis dapat disimpulkan bahwa:

- Career growth secara positif dan signifikan mempengaruhi kepuasan kerja. Hal tersebut sesuai dengan penelitian Riaz dan Haider (2010), pertumbuhan karir yang baik mempengaruhi kepuasan kerja karyawan secara positif. Karyawan akan merasa puas terhadap pekerjaannya apabila hasil kerjanya diapresiasi dengan salah satu caranya adalah kenaikan jenjang karir.

- Career growth secara tidak signifikan memiliki pengaruh positif terhadap turnover intention. Hal ini sesuai dengan penelitian Gulsah (2014). Faktor pertumbuhan karir yang baik bagi karyawan tidak menarik dibanding faktor lain seperti kompensasi dan kepuasan kerja.

- Kompensasi mempengaruhi kepuasan kerja secara signifikan dan positif. Penelitian ini sesuai dengan hasil penelitian Nurcahyani dan Adnyani (2016) dan penelitian Muguongo, Muguna, dan Muriithi (2015) serta Yaseen (2013) yang membuahkan hasil penelitian bahwa kompensasi dapat mempengaruhi kepuasan kerja karyawan secara postif dan signifikan. Hal tersebut menandakan bahwa kompensasi yang diberikan perusahaan sebagai tanda apresiasi terhadap karyawan akan meningkatkan kepuasan kerja.

- Kompensasi mempengaruhi secara positif terhadap turnover intention. Hal ini berlawanan dengan penelitian Evelyn et al (2013) yang menyaakan bahwa kepuasan kerja tidak memiliki pengarh siginifikan terhadap turnover intention karyawan. Tingginya kompensasi yang diberikan pada karyawan menandakan besarnya apresiasi perusahaan terhadap karyawan dan dapat membuat karyawan lebih ingin bertahan di perusahaan tersebut.

- Job satisfaction mempengaruhi turnover intention secara positif dan signifikan. Hal tersebut sesuai dengan pelitian Awang, Amir dan Osman (2013) yang menyatakan bahwa faktor kepuasan kerja seperti gaji, promosi, supervise, tunjangan, kontingen imbalan, operasi kondisi, rekan kerja, lingkungan perkerjaan, dan komunikasi merupakan faktor yang mempengaruhi turnover intention secara signifikan. Dengan melihat nilai signifikansinya, terlihat bahwa karyawan akan lebih mementingkan kepuasan kerja 
dibanding kompensasi untuk turnover intention karena nilai signifikansi kepuasan kerja lebih kecil.

- Career growth, compensation dan job satisfaction mempengaruhi turnover intention secara positif dan signifikan. Kepuasan kerja dapat dijadikan sebagai mediator antara pertumbuhan karir dan kompensasi yang mempengaruhi turnover intention sebagai variabel dependen. Hal tersebut sesuai dengan penelitian Awang, Amir dan Osman (2013) sehingga kepuasan kerja dapat menjadi isu utama bagi perusahaan untuk mempertahankan karyawannya.

- Career growth dan compensation mempengaruhi turnover intention secara positif dan signifikan. Kedua variabel independen mempengaruhi Turnover Intention karyawan dimana karyawan merasa terapresiasi atas hasil kerjanya dengan adanya pertumbuhan karir yang cepat dan tinggi serta pemberian kompensasi yang tinggi sesuai dengan kinerja karyawan sehingga karyawan akan bertahan di suatu perusahaan.

- Penelitian ini memberikan hasil bahwa masing-masing variabel independen yaitu career growth, compensation dan job satisfaction memberikan pengaruh lebih besar dibanding menggunakan job satisfaction sebagai variabel mediasi.

\section{Saran}

Adapun keterbatasan dalam penelitian ini yang mungkin mempengaruhi hasil penelitian adalah keterbatasan dalam penelitian ini terletak pada adanya keterbatasan waktu dan sumber daya peneliti sehingga data yang diperoleh hanya terbatas pada 164 responden pada satu perusahaan. Selain itu, data yang digunakan untuk penelitian selanjutnya dapat menggunakan longitudinal.

- Bagi Manajerial

$>$ Berdasarkan hasil penelitian, maka perusahaan sebaiknya memperhatikan faktorfaktor yang dapat terkait dengan kepuasan kerja untuk meningkatkan turnover intention-nya.

$>$ Berdasarkan penelitian ini juga menyatakan pentingnya faktor-faktor seperti pertumbuhan karir dan kompensasi dapat mempengaruhi kepuasan kerja yang merupakan faktor mediasi turnover intention sehingga perusahaan dapat memberikan peningkatan pada kedua faktor tersebut.

- Bagi Peneliti Selanjutnya

Peneliti selanjutnya disarankan untuk menambah jumlah variabel lain yang dapat berkontribusi lebih besar dan signifikan baik dalam menentukan kepuasan kerja maupun turnover intention.

\section{DAFTAR PUSTAKA}

Amran Awang, Abdul Razak Amir, Wirda Osman, Job Behavioral Factors and Turnover Intention: A Case Study at Sime Darby Property Limited, Universiti Teknologi MARA, Malaysia. International Journal of Advances in Management and Economics, ISSN: 22783369

Karavardar, Gulsah, Organizational Career Growth and Turnover Intention: An application in Audit Firms in Turkey, Faculty of Economic and Administrative Sciences, Giresun University, Giresun, Turkey, International Business Research, ISSN 1913-9004

Evelyn Tnay, Abg Ekhsan Abg Othman*, Heng Chin Siong, Sheilla Lim Omar Lim, The influences of job satisfaction and organizational commitment on turnover intention. Diambil dari sumber www.sciencedirect.com/

Oya Erdila, Büşra Müceldili, The Effects of Envy on Job Engagement and Turnover Intention. Diambil dari sumber www.sciencedirect.com/

Saeed, Iqra, The relationship of Turnover intention with job satisfaction, job performance, Leader member exchange, Emotional intelligence and organizational commitment, 
Department of Management Sciences, The Islamia University of Bahawalpur, Pakistan, International Journal of Learning \& Development, ISSN 2164-4063

Hidayat, Anwar. Penjelasan Tentang Uji Normalitas dan Metode Perhitungan. Th. 2013. Diambil dari sumber : https://www.statistikian.com/2013/01/uji-normalitas.html

Hidayat, Anwar. Tutorial Uji Normalitas Kolmogorov Smirnov dengan SPSS. Th. 2012. Diambil dari sumber : https://www.statistikian.com/2012/09/uji-normalitas-dengankolmogorov-smirnov-spss.html

DMK, Maruli. Artikel : Pengertian Turnover Menurut Para Ahli. Th. 2012. Diambil dari sumber : http://xerma.blogspot.co.id/2014/04/pengertian-turnover-menurut-para-ahli.html

Jehan, Sarah. Skripsi : Analisa Faktor - Faktor Yang Mempengaruhi Turnover Intention Pada Perawat Rsia. Hermina. Jakarta, Th. 2015. Diambil dari Sumber: http://www.academia.edu/14992812/analisa_faktor_faktor_yang_mempengaruhi_turnover_i ntention_pada_perawat_rsia._hermina

Refiana, said, Layla. Pengaruh Kompensasi Finansial Dan Non Finansial Terhadap Kepuasan Kerja Serta Dampaknya Terhadap Turnover Intention Pada Pelaut di PT. Maritim Barito Perkasa Banjarmasin. Th. 2016. Diambil dari sumber : https://www.researchgate.net/publication/308800434_Pengaruh_Kompensasi_Finansial_Da n_Non_Finansial_Terhadap_Kepuasan_Kerja_Serta_Dampaknya_Terhadap_Turnover_Inte ntion_Pada_Pelaut_di_PT_Maritim_Barito_Perkasa_Banjarmasin

Irbayuni, Sulastri. (2012). "Pengaruh Kompensasi, Kepuasan Kerja dan Komitmen Organisasi Terhadap Keinginan Untuk Pindah Kerja pada PT. Surya Sumber Daya Energi Surabaya”. Jurnal NeO-Bisnis . Vol. 6, No. 1.

Metodologi Penelitian BAB 3. UNPAS. Diambil dari sumber : http://repository.unpas.ac.id/30278/4/BAB\%20III.pdf 
